\title{
INFLUENCE OF AGE AND SEASON ON PRODUCTIVITY OF SPERM OF HOLSTEIN BULLS - SPERM PROVIDERS IN CONDITIONS OF LLC «UKRAINIAN GENETIC COMPANY»
}

\section{Daria Zakharchuk $^{1}$}

DOI: https://doi.org/10.30525/978-9934-26-050-6-9

Efficiency of seed bulls is characterized by the number of their offspring which mainly depends on the quality of ejaculates and insemination ability of sperm cells.

Numerous scientific researches suggest that notable variability of sperm efficiency of bulls - sperm providers is predetermined by a number of genetic as well as paratypic factors [2, p. 971; 3, p. 3219; 6, p. 3321]. The majority of scientists noticed that quantity and quality of semen is essentially influenced by the season. Boiko O. V. and others in their researches have ascertained that motility of sperm of Holstein bulls is better in winter-autumn period, the highest concentration of sperm cells in ejaculate is in winter season and the lowest - in spring, volume of ejaculate during all seasons is almost the same with slight decrease in spring by 7,36 \% [1, p. 222]. Snoj and others observed high volume of ejaculates in spring-summer period, and maximum concentration of sperm cells - in summer [8, p. 849]. Kuzebnyi S. V. [5, p. 18]

\footnotetext{
${ }^{1}$ Polissya National University, Ukraine
} 
has not observed season changes of sperm efficiency of Holstein bulls and related domestic breeds.

Another important factor related to sperm parameter is age. According to Siratskyi Y. Z. and others [7, p.13] age of bulls influences volume of ejaculate depending on the breed by 24,2-30,1\%, concentration of sperm cells by $2,6-15,2 \%$, their motility - by $4,3-18,3$, persistence of sperm cells to freezing - by $8,5-15,8 \%$.

Study of influence of these factors on quantity and quality characteristics of sperm efficiency will help breeding companies to organize work with bulls - sperm providers efficiently and increase yield of high-quality sperm. In view of the aforesaid, the objective of our research is study of age and season influence on productivity of sperm of Holstein bulls - sperm providers in conditions of LLC «Ukrainian Genetic Company».

The research was carried out with 20 Holstein bulls - sperm providers of black- and red-spotted coat color. As materials for the research were used sperm accounting records kept for bulls - sperm-providers, form \#1-mol. «Seed bull record» and the results of own laboratory examinations. Volume of ejaculate, concentration of sperm cells in $1 \mathrm{ml}$ of sperm and motility of sperm cells were counted on sperm analyzer IVOS (system CASA). Quality of native sperm was assessed according to DSTU 3535-97. Primary data was processed using variation statistics methods on computer software «MS Office Excel 2010».

The age of the experimental bulls ranged from 3 to 12 years. In order to study the influence of bulls' age on the productivity of their sperm bulls were divided into 3 age groups: I - 3-4 years, II - 5-10 years, III - 11-12 years. According to the researches of laboratory workers from the Institute of Animal Breeding and Genetics nd. a. M. V. Zubets of NAAS, genital function of bulls - sperm providers is formed during the period starting from their sexual maturation and lasts until they become 2 years of age and is characterized by constant increase of the volume of ejaculate, concentration of sperm cells in ejaculate, their motility and persistence to freezing; physiological maturity begins at 2 and lasts until 5 years of age and is characterized by the increase of the said characteristics; stabilization of genital function takes place from 5 until 10-12 years of age; failure of genital function starts after 12 years of age [4, p. 711].

Analysis of characteristics of sperm productivity depending on age showed, that Holstein bulls of foreign selection are most sexually active at the age of 3-4 years (146 high-quality ejaculates during a year), they produced the largest quantity of native sperm $(731,5 \mathrm{ml})$ with highest concentration of sperm cells in ejaculate $(3,20 \mathrm{bln} / \mathrm{ml})$ and motility $(8,1$ points $)$ as a result they produced maximum quantity of sperm doses $(44918$ pcs.) $(\mathrm{P}<0,001 \ldots 0,01)$. 
It should be noted, that during 2 years of research characteristics of these young bulls have remained the same (Bugatti, Laski, Faun) or even decreased (Argonaut, Levitz). It means, that examined Holstein bulls - sperm providers of foreign selection turned out to be earlier-maturing, their genital function becomes stable 5 years earlier. Research of Kuzebnyi S. V. [5, p.16] also proves absence of differences in characteristics of sperm productivity of sperm providing bulls of foreign selection from 3 to 8 years of age. As regards two other age groups (5-10 and 11-12 years) no possible difference in their characteristics has been found. During one year they produced $78,0-92,4$ ejaculates, 389,7-480,3 $\mathrm{ml}$ of sperm, concentration of sperm cells in $1 \mathrm{ml}$ is $2,07-2,28 \mathrm{bln} / \mathrm{ml}$, yield of sperm doses is $15068-22955$ pcs. There is no substantial difference in volume of ejaculate $(4,93-5,3 \mathrm{ml})$ and persistence of sperm cells to freezing $(89,1-92,4 \%)(\mathrm{P}>0,05)$ between three age groups. Thus, differences between groups are not associated with age, but with individual characteristics of bulls - sperm providers - like genotype, state of reproductive system, type of higher nervous system, adaptive ability, etc.

Another important factor that influences sperm productivity of bulls is season. The researches that we have undertaken evidence significant increase of sexual activity of sperm providers and productivity of their sperm observed in spring. During spring season maximum quantity of quality ejaculates was received from one bull $(31,6$ pcs., $\mathrm{P}<0,05)$ and native sperm $(158,0 \mathrm{ml}$, $\mathrm{P}>0,05)$. In other seasons the said characteristics were $24,3-26,1$ pcs. and $127,8-128,2$ respectively.

Most sperm doses were frozen in winter-spring seasons - 7851-8069 pcs. obtained from 1 sperm provider. Volume of ejaculate during this period equaled to 4,90-5,00 ml, concentration of sperm cells in $1 \mathrm{ml}-2,52-2,53 \mathrm{bln}$, motility of sperm cells in ejaculate is higher in winter ( $+0,3$ points).

In summer-autumn bulls produced in average 7 ejaculates and $30 \mathrm{ml}$ of native sperm less than in spring $(\mathrm{P}<0,05 \ldots>0,05)$ as a result less quantity of sperm doses was obtained - 6149-6293 pcs. Instead, in summer maximum volume of ejaculate is produced $(5,28 \mathrm{ml}, \mathrm{P}<0,001 \ldots>0,05)$ as well as concentration of sperm cells in $1 \mathrm{ml}(2,78 \mathrm{bln}, \mathrm{P}<0,001)$, it may be due to feeding dried herbage to bulls.

Volume of ejaculate since December until April is minimal, its increase takes place in May. Maximal figure was recorded in June - 5,46 ml. Since July until November fluctuations are observed within the range $5,10 \mathrm{ml}$ (August) - 5,32 ml (September) (Figure 1).

Minimal concentration of sperm cells in ejaculates $(2,40 \mathrm{bln} / \mathrm{ml})$ was recorded in January. Since February until August was observed gradual increase (from 2,49 until 3,00 bln/ml), decline has started again since September. 


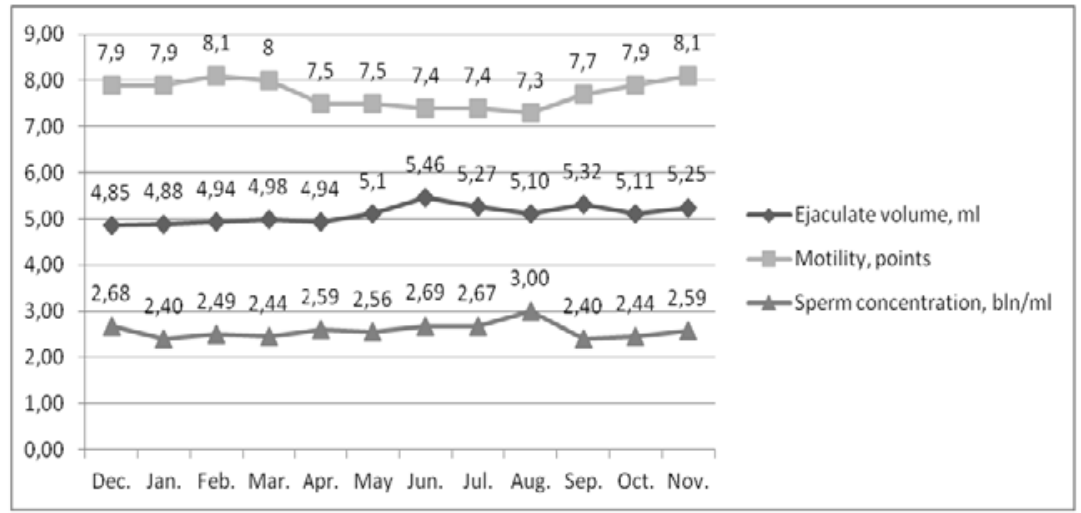

Figure 1. Dynamics of main sperm characteristics during a year

Motility of sperm cells in ejaculate since December until March ranges from 7,9-8,1 points, since April until August gradual decline to 7,3 points is observed, since September until the end of the year - again rise to 8,1 points.

\section{References:}

1. Boiko O. V., Siratskyi Y. Z., Fedorovych Ye. I., Fedorovych V. V. (2012) Rist ta vidtvorna zdatnist buhaiv pid vplyvom riznykh chynnykiv [Growth and reproductive capacity of bulls under the influence of various factors]. Breeding and Genetics of Animals, vol. 46, pp. 220-223.

2. Boujenane I. and Boussaq K. (2013) Environmental effects and repeatability estimates for sperm production and semen quality of Holstein bulls. Archiv. Tierzucht. 56(98): 971-979 doi: 10.7482/0003-9438-56-096

3. Gopinathan, A., Sivaselvam, S. N., Karthickeyan, S. K., Kulasekar, K., Kirubaharan, J. John and Venkataramanan, R. (2018) Effect of Non-genetic factors on Semen Quality Traits of Crossbred Holstein Friesian Bulls (Bos taurus x Bos indicus) in Organized Farming Conditions at Tamil Nadu, India. International Journal of Current Microbiology and Applied Sciences, 7(11): 3219-3229. doi: 10.20546/ ijcmas.2018.711.370

4. Kyzebnyy, S. V., Boiko, O. V. (2018) Otrymannia, otsinka, zberihannia ta vykorystannia spermy plidnykiv silskohospodarskykh tvaryn [Obtaining, evaluating, storing and using sperm of sires of farm animals]. Selektsiini, henetychni ta biotekhnolohichni metody udoskonalennia i zberezhennia henofondu porid silskohospodarskykh tvaryn [Breeding, genetic and biotechnological methods of improvement and preservation of the gene pool of farm animals]. In M. V. Hladii \& Yu. P. Polupan (Eds.). Poltava: LLC «Techservice Company», pp. 709-720.

5. Kuzebnyi, S. V. (2008) Vplyv henetychnykh ta paratypovykh factoriv na vidtvoriuvalnu zdatnist buhaiv-plidnykiv [Influence of genetic and paratypic factors on 
reproductive capacity of breeding bulls]. Abstract of $\mathrm{PhD}$ dissertation. Chubynske, Kyiv region.

6. Mathevon M., Buhr M.M, Dekkers J. C (1998) Environmental, management, and genetic factors affecting semen production in Holstein bulls. J Dairy Sci., 81(12): 3321-30. doi: 10.3168/jds.S0022-0302(98)75898-9

7. Siratskyi, Y. Z., Fedorovych, Ye. I., Fedorovych, V. V., Kadysh V. O., Piddubna L. M. (2008) Fizioloho-biokhimichni ta biotekhnolohichni pocaznyky spermy buhaiv-plidnykiv [Physiological, biochemical and biotechnological parameters of sperm of breeding bulls]. Kyiv: Liuksar. (in Ukrainian)

8. Snoj T., Kobal S., Majdic G. (2013) Effects of season, age, and breed on semen characteristics in different bos taurus breeds in a 31-year retrospective study. Theriogenology, 79: 847-852. doi: 10.1016/j.theriogenology.2012.12.014 